\title{
Borrowed objects \\ and the art of poetry \\ Spolia in Old English verse
}

DENIS FERHATOVIĆ

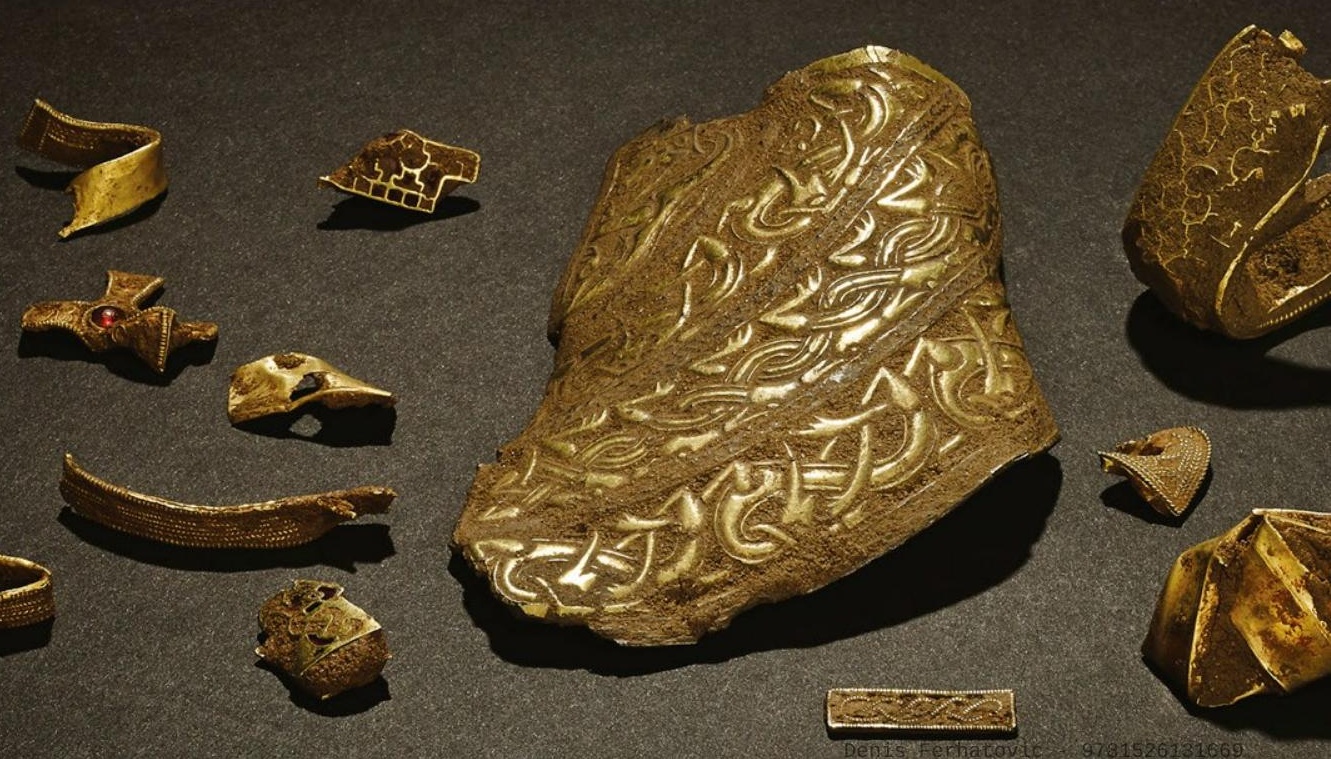




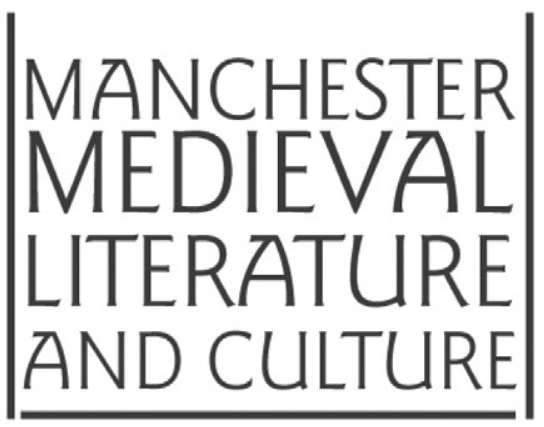

BORROWED OBJECTS AND

THE ART OF POETRY

\section{MANCHESTER 1824}

Manchester University Press 
Series editors: Anke Bernau, David Matthews and James Paz

Series founded by: J. J. Anderson and Gail Ashton

Advisory board: Ruth Evans, Patricia C. Ingham, Andrew James Johnston, Chris Jones, Catherine Karkov, Nicola McDonald, Sarah Salih, Larry Scanlon and Stephanie Trigg

Manchester Medieval Literature and Culture publishes monographs and essay collections comprising new research informed by current critical methodologies on the literary cultures of the Middle Ages. We are interested in all periods, from the early Middle Ages through to the late, and we include post-medieval engagements with and representations of the medieval period (or 'medievalism'). 'Literature' is taken in a broad sense, to include the many different medieval genres: imaginative, historical, political, scientific, religious. While we welcome contributions on the diverse cultures of medieval Britain and are happy to receive submissions on Anglo-Norman, Anglo-Latin and Celtic writings, we are also open to work on the Middle Ages in Europe more widely, and beyond.

\section{Titles available in the series}

11. Reading Robin Hood: Content, form and reception in the outlaw myth Stephen Knight

12. Annotated Chaucer bibliography: 1997-2010

Mark Allen and Stephanie Amsel

13. Roadworks: Medieval Britain, medieval roads

Valerie Allen and Ruth Evans (eds)

14. Love, history and emotion in Chaucer and Shakespeare: Troilus and Criseyde and Troilus and Cressida

Andrew James Johnston, Russell West-Pavlov and Elisabeth Kempf (eds)

15. The Scottish Legendary: Towards a poetics of hagiographic narration Eva von Contzen

16. Nonhuman voices in Anglo-Saxon literature and material culture James Paz

17. The church as sacred space in Middle English literature and culture Laura Varnam

18. Aspects of knowledge: Preserving and reinventing traditions of learning in the Middle Ages

Marilina Cesario and Hugh Magennis (eds)

19. Visions and ruins: Cultural memory and the untimely Middle Ages Joshua Davies

20. Participatory reading in late-medieval England Heather Blatt

21. Affective medievalism: Love, abjection and discontent Thomas A. Prendergast and Stephanie Trigg

22. Performing women: Gender, self, and representation in late-medieval Metz Susannah Crowder

23. The politics of Middle English parables: Fiction, theology, and social practice Mary Raschko

24. Contemporary Chaucer across the centuries

Helen M. Hickey, Anne McKendry and Melissa Raine (eds)

25. Borrowed objects and the art of poetry: Spolia in Old English verse

Denis Ferhatović 


\section{Borrowed objects and the art of poetry}

Spolia in Old English verse

DENIS FERHATOVIĆ

Manchester University Press 
The right of Denis Ferhatović to be identified as the author of this work has been asserted by him in accordance with the Copyright, Designs and Patents Act 1988.

Published by Manchester University Press

Altrincham Street, Manchester M1 7JA

www.manchesteruniversitypress.co.uk

British Library Cataloguing-in-Publication Data

A catalogue record for this book is available from the British Library

ISBN 9781526131652 hardback

First published 2019

The publisher has no responsibility for the persistence or accuracy of URLs for any external or third-party internet websites referred to in this book, and does not guarantee that any content on such websites is, or will remain, accurate or appropriate.

Typeset

by Toppan Best-set Premedia Limited 